\title{
Prevalence of Anemia in Children Aged Six Months to Thirty Six Months - A Hospital Based Study
}

\author{
HUMAIRA RAFIQA QUADERI ${ }^{1}$, MD. MAHBUBUL HOQUE ${ }^{2}$, NAWSHAD UDDIN AHMED ${ }^{3}$, DILRUBA \\ BEGUM $^{4}$, BITHI DEBNATH ${ }^{5}$
}

\begin{abstract}
Background: Anemia is a common problem in childhood, especially children aged 6months to 24 months old. In Bangladesh overall, $68 \%$ of children aged 6-59 months are anemic. Anemia impairs normal development, decreases physical exercise tolerance \& intellectual performance in children which may lead to a slowdown of growth in children. It constitutes a major public health problem in young children in the developing world with wide social \& economic implications.

Objective: To see the prevalence of anemia among hospitalized children aged 6 months to 36 months.

Methodology: Children 6 months -36 months aged who were admitted in Dhaka Shishu (Children) hospital due to some acute illness, were enrolled from $1^{\text {st }}$ June, 2010 to 30th August, 2010. Children were classified as anemic when $\mathrm{Hb}$ level was $<11 \mathrm{gm} / \mathrm{dl}$. On the values of MCV and morphology of RBC anemic babies were further classified as microcytic anemia, normocytic anaemia and macrocytic anaemia. Again in children with microcytic hypochromic RBC, serum ferritin, $\mathrm{Hb}$ electrophoresis, stool $R / E$ and c-reactive protein were done to find out the cause.

Results: Among 331 admitted children, 201(61\%) children had anemia ( $\mathrm{Hb}<11 \mathrm{gm} /$ dl), Male was 123(61.2\%) and female was 78(38.8\%). Mean hemoglobin concentration was $9.2 \pm 1.2 \mathrm{gm} / \mathrm{dl}$. Mild, moderate, severe anemia were $19 \%, 39.3 \%$ and $2.4 \%$ respectively. The most affected age group was 6-23 months(76\%). Microcytic anemia, macrocytic anemia, and normocytic anemia were present in 101(50.2\%), 10(5\%) and 90(44.8\%) cases respectively. Among the microcytic hypochromic anemia, IDA was found in 60(59.4\%), which was $29.85 \%$ among total anemic children.

Conclusion: A large proportion of hospitalized children under 3 years were found anemic. Raising awareness of the problem and providing health care education in this group will be the key strategies to prevent and control this huge public health problem in Bangladesh.
\end{abstract}

Key words: Anaemia, Hemoglobin, Prevalence.

\section{Introduction}

Anemia is defined as a reduction of the red blood cell (RBC) volume or hemoglobin concentration below the range of values occurring in healthy person. ${ }^{1}$ Anemia is a common problem in childhood, especially children

1. Resident Medical Officer, Dhaka Shishu (Children) Hospital, Sher-e Bangla Nagar, Dhaka.

2. Professor of Neonatology, Institute of Child Health, Dhaka Shishu (Children) Hospital, Sher-e Bangla Nagar, Dhaka.

3 Professor of pediatrics. Institute of Child Health, Dhaka Shishu (Children) Hospital, Sher-e Bangla Nagar, Dhaka.

4. Associate Professor of Physiology, Dhaka Medical College.

5. Assistant Professor, National Institute of Neuroscience, Dhaka.

Correspondence: Dr. Humaira Rafiqa Quaderi, Resident Medical

Officer, Dhaka Shishu (Children) Hospital, Sher-e Bangla Nagar,

Dhaka, E-mail:dr.humaira25th@gmail.com aged 6 months to 24 months old. It has been estimated that among children below four years of age, $12 \%$ are anemic in developed countries and $51 \%$ are anemic in developing countries. ${ }^{2}$ In Bangladesh $64 \%$ of children aged 6-23 months and $42 \%$ of children aged $24-59$ months are anemic. ${ }^{3}$ Another survey in Bangladesh conducted by national Surveillance Project (NSP) of Helen Keller International (HKI) in collaboration with the Institute of Public Health Nutrition (IPHN) in 2004 showed that, overall, $68 \%$ of children aged 6-59 months were anemic. ${ }^{4}$

Anemia impairs normal development in children and it constitutes a major public health problem in young 
children in the developing world with wide social \& economic implications. Thus decreased physical exercise tolerance \& intellectual performance have been associated with mild anemia, which may lead to a slowdown of growth in children. ${ }^{5,6}$ Anemia is commonly associated with nutritional deficiencies such as iron deficiency, the main factor responsible for microcytic anemia, while folate or vitamin B12 deficiencies are responsible for macrocytic anemia. ${ }^{5,7}$ Among the causes of anemia, iron deficiency anemia (IDA) is the most commonly recognized form of nutritional deficiency in developing \& developed countries ${ }^{5,8}$ According to the world health organization, IDA affects $43 \%$ of the world's children ${ }^{2}$ $\&$ according to UNICEF report, 2 billion people suffer from anemia worldwide \& most of them have IDA, especially in underdeveloped / developing countries, where $40-50 \%$ of children under age 5 are iron deficient. ${ }^{9}$ This study designed to determine the prevalence of anemia in 6months to 36 months old hospitalized children who were admitted due to some acute illness.

\section{Materials and Methods}

This cross-sectional study was conducted in Dhaka Shishu (Children's) Hospital (DSH) over a period of three months from $1^{\text {st }}$ June 2010 to $30^{\text {th }}$ August 2010. Children aged six months to thirty six months, who were admitted during this period due to any acute illness like acute respiratory tract infection, acute gastroenteritis, etc., and whose parent or guardian provided informed consent, were eligible for enrolment. Children who have been suffering from chronic illness such as hematological and renal disorders, severe malnutrition, persistent diarrhea and who received blood transfusion before admission due to any cause were excluded from the study.

At enrolment a detailed case history was taken and thorough physical examination was performed and recorded on standard case record forms. Historical information included socioeconomic status (parents' education and monthly income), birth history (prematurity, low birth weight) and detailed feeding practice since birth was recorded. Laboratory investigations: Complete blood count (CBC) including peripheral blood film was done in all cases on enrolment. A blood sample $(2 \mathrm{ml})$ was collected by venepuncture into an ethylenediaminetetraacetic acid (EDTA) coated tube. The cell counter machine was used for the values of hemoglobin $(\mathrm{Hb})$, erythrocyte count and mean corpuscular volume (MCV). Anemia was defined when $\mathrm{Hb}$ level was below $<11 \mathrm{~g} / \mathrm{dL}$ according to World Health Organization (WHO) Children were categorized as children with anemia $(\mathrm{Hb}<11 \mathrm{gm} / \mathrm{dl})$ and children without anemia $(\mathrm{Hb}>11 \mathrm{gm} / \mathrm{dl})$. Anemia was labeled as mild $(\mathrm{Hb} 10-$ $10.9 \mathrm{gm} / \mathrm{dl})$, moderate $(\mathrm{Hb} 7-9.9 \mathrm{gm} / \mathrm{dl})$, and severe $(\mathrm{Hb}$ $<7 \mathrm{gm} / \mathrm{dl}$ ). ${ }^{10}$ Furthermore, on the value of MCV (Normal values: $3-6$ mon- $76 \pm 8 f l ; 1$ year- 78 $\pm 6 f l$; 2-6years$81 \pm 6 \mathrm{fl}$ ) and morphology of RBC from peripheral blood film, ${ }^{11}$ anemia was classified as microcytic (low $\mathrm{MCV}$ ), normocytic (normal MCV), and macrocytic (high MCV). ${ }^{12}$

In addition, if peripheral blood film showed microcytic hypochromic RBC, further investigations for serum ferritin ( $2 \mathrm{ml}$ blood, collected in a plain test tube for the measurement of serum ferritin by immunoenzymometric examination), routine and microscopic examination of stool, hemoglobin electrophoresis and C-reactive protein (CRP) were performed. Iron deficiency anemia was defined when concentration of serum ferritin were less than 12 microgram/L. ${ }^{13}$ Serum Iron and TIBC could not be performed due to financial reason. Ethical permission was taken from Ethical Review Committee of Bangladesh Institute of Child Health. Informed written consent was obtained from parents or primary caregivers of the children before enrolment. Results of laboratory tests were communicated to the parents. Advice for prevention of anaemia was given and correction was done when needed. The data were entered and analyzed using SPSS version 12.0 for Windows (SPSS Inc, Chicago, IL, USA) software. Standard test for significance using Chi-square (Ç2) test and multivariate predictor analysis were performed. A $p$-value of $<0.05$ was considered as statistically significant.

\section{Results}

A total of 384 children were screened during the study period, among them 331 cases were enrolled. Fiftythree $(13.8 \%)$ cases could not be enrolled because of not giving consent for venepuncture $(n=46)$ and insufficient collection of blood for estimation of serum ferritin $(n=7)$. Out of the 331 enrolled children, 201 $(61 \%)$ had anemia $(\mathrm{Hb}<11 \mathrm{gm} / \mathrm{dl})$ while $130(39 \%)$ had normal hemoglobin concentration $(\mathrm{Hb}>11 \mathrm{gm} / \mathrm{dl})$ (Fig.- 1). Among the anemic children, 63 (31.3\%) had mild anemia, 130 (64.7\%) were moderately anemic and $8(4 \%)$ were severely anemic. Among 205 male 
children, 123 (61.2\%) were anemic and among 126 female children, $78(38.8 \%)$ were anemic; the difference between gender was not statistically significant (Table-l). The mean ( \pm SD) hemoglobin levels were $9.2 \pm 1.2 \mathrm{~g} / \mathrm{dl}$ in children with anemia, and $11.9 \pm 1.0$ $\mathrm{g} / \mathrm{dl}$ in children without anemia. Hemoglobin levels was significantly low in anemic children $(P=0.001)$ than children without anemia (Table-II). The study patients were divided into three age groups. Maximum number was found in 12-23 months in both anemic and non anemic children which was $83(41.21 \%)$ in children with anemia and $62(47.69 \%)$ in children without anemia. The mean $( \pm S D)$ age was $15.2 \pm 8.8$ month for children with anemia and $18.6 \pm 9.3$ month for children without anemia. The mean age difference was statistically significant $(p<0.001)$. The most affected group was 6-23 months age ( $76.12 \%$ ) ( Table -III). Again among total study patients $(n=331)$, mild, moderate and severe anemia were found as $63(19 \%)$, 130(39.3\%), 8(2.4\%) respectively and normal $\mathrm{Hb}$ 130(39.3\%) (fig.-2). Microcytic anemia was observed in $101(50.2 \%)$ cases, macrocytic anemia in $10(5 \%)$ cases and normocytic anemia in $90(44.8 \%)$ cases (Fig.-3). Among 101 patients with microcytic hypochromic anemia, IDA was identified in 60 (59.4\%) cases, $B$-thalassaemia trait in $10(9.9 \%)$ cases and B-thalassaemia in one (1\%) case. However 30 (29.7\%) cases were left undetermined (Table-IV). Prevalence of IDA among the total anemic children was $29.85 \%$ (60 out of 201). The undetermined cases were those who had serum ferritin level $>12$ microgram/ $L$, a normal $\mathrm{Hb}$ electrophoresis pattern, and a high CRP level.

Table-I

Sex distribution of the study patients $(n=331)$

\begin{tabular}{lccccc}
\hline Sex & \multicolumn{2}{c}{$\begin{array}{c}\text { children with anemia } \\
(\mathrm{n}=201)\end{array}$} & \multicolumn{2}{c}{ children without anemia } & P value \\
& $\mathrm{N}$ & $\mathrm{n}=130)$ & $\mathrm{n}$ & \\
\hline Male & 123 & 61.2 & 82 & 63.1 & $0.730^{\mathrm{ns}}$ \\
Female & 78 & 38.8 & 48 & 36.9 & \\
\hline Total & 201 & $100 \%$ & 130 & $100 \%$ & \\
\hline
\end{tabular}

$\chi^{2}=0.12, d f=1, p=0.730$

Table- II

Hemoglobin levels in study patients $(n=331)$

\begin{tabular}{lccc}
\hline & $\begin{array}{c}\text { Children with anemia } \\
(\mathrm{n}=201)\end{array}$ & $\begin{array}{c}\text { Children without anemia } \\
(\mathrm{n}=130)\end{array}$ & P values \\
\hline Hemoglobin $(\mathrm{g} / \mathrm{dl})($ mean $\pm \mathrm{SD})$ & $9.2 \pm 1.2$ & $11.9 \pm 1.0$ & 0.001 \\
\hline
\end{tabular}

Independent sample ' $\mathrm{t}$ ' test

Table-III

Age distribution of the study patients ( $n=331)$

\begin{tabular}{|c|c|c|c|c|c|}
\hline \multirow[t]{2}{*}{ Age in months } & \multicolumn{2}{|c|}{$\begin{array}{c}\text { Children with } \\
\text { anemia }(n=201)\end{array}$} & \multicolumn{2}{|c|}{$\begin{array}{l}\text { Children without } \\
\text { anemia }(n=130)\end{array}$} & \multirow[t]{2}{*}{ Pvalue } \\
\hline & $\mathrm{N}$ & $\%$ & $\mathrm{~N}$ & $\%$ & \\
\hline 6-11 mon & 70 & 34.83 & 35 & 26.92 & \\
\hline $12-23$ mon & 83 & 41.29 & 62 & 47.69 & $0.001^{*}$ \\
\hline 24-36 mon & 48 & 23.88 & 33 & 25.39 & \\
\hline Total & 201 & $100 \%$ & 130 & $100 \%$ & \\
\hline Mean \pm SD & \multicolumn{2}{|c|}{$15.2 \pm 8.8$} & \multicolumn{2}{|c|}{$18.6 \pm 9.3$} & $0.001^{* *}$ \\
\hline Range (Min- Max) & \multicolumn{2}{|c|}{$(6-36)$} & \multicolumn{2}{|c|}{$(6-36)$} & \\
\hline
\end{tabular}

* $\chi^{2}=3.337, \mathrm{df}=329, \mathrm{p}$ value $=0.001$

** Independent sample ' $t$ ' test 
BANGLADESH J CHILD HEALTH 2016; VOL 40 (2) : 101

Table-IV

Causes of microcytic hypochromic anaemia $((n=101)$

\begin{tabular}{lcc}
\hline $\begin{array}{l}\text { Causes of microcytic } \\
\text { hypochromic anemia }\end{array}$ & $\begin{array}{c}\text { Number of } \\
\text { patients(n) }\end{array}$ & $\begin{array}{c}\text { Percentage } \\
(\%)\end{array}$ \\
\hline IDA & 60 & 59.4 \\
BetaThalassaemia Trait & 10 & 9.9 \\
Beta Thalassaemia & 1 & 1.0 \\
Undetermined & 30 & 29.7 \\
\hline Total & 101 & $100 \%$ \\
\hline
\end{tabular}

Discussion

The prevalence of anemia varies widely between the countries. Different surveys in the past have shown that anemia is a severe problem in Bangladesh among all age, population and geographic groups. ${ }^{14,15,16} \mathrm{In}$ this study, 61\%( $n=201)$ children had anemia $(\mathrm{Hb}$ $<11 \mathrm{gm} / \mathrm{dl}$ ). According to a National Surveillance Project (NSP) of Helen Keller International (HKI) in collaboration with the Institute of Public Health Nutrition (IPHN), overall $68 \%$ of Bangladeshi children aged 6-59 months had anemia. ${ }^{17}$ The prevalence of anemia in India was $74.35 \%$ for $6-35$ months age group, Nepal had $78 \%$ for $6-59$ months age group and in Kazakhstain it was $73.7 \%$ for $0-23$ months age group. ${ }^{18}$ The prevalence of anemia in preschool children (0-4 yr) of WHO countries of Africa, southeast Asia and eastern Mediterranean were $67.6 \%$, $65.5 \%$ and $46.7 \%$ cases respectively. ${ }^{19}$ The prevalence of anemia is much more lower in developed countries such as in America 29.3\% and Europe $21.7 \% .^{19}$

By using the WHO /UNICEF/UNN classification in this study, it was found that $19 \%$ had mild, $39.3 \%$ had moderate and $2.4 \%$ had severe anemia (Fig.-2). In a study done in Nigeria showed that $70.5 \%(n=400)$ children had varying degrees of anemia. Among the anemic cases mild, moderate and severe anemia were $38.0 \%, 31.8 \%$ and $0.8 \%$ respectively. The most affected age group was 6-23 months (76.12\%). This result was similar to study in Nigeria, where Onyemaobi et al found the most affected age group was $12-23$ months $(84.8 \%) .{ }^{20}$ In a study done in Bangladesh in 1994, the prevalence of anemia was 92\% among 6-11 month age group and $85 \%$ among $12-23$ month age group. The most affected group was 6-23 months ( $87 \%) \cdot{ }^{16}$ In this study the prevalence of anemia in male was higher $123(61.2 \%)$ than female
Prevalence of Anemia in Children, among Aged 6 - 36 Six Months

$78(38.8 \%)$ and the mean hemoglobin concentration was $9.2 \pm 1.2 \mathrm{gm} / \mathrm{dl}$. This findings are similar to a study in Bangladesh where boys $(n=641)$ were more anemic than girls $(n=586)$ and mean hemoglobin concentration in 6-59 month age group was $10.2 \mathrm{gm} / \mathrm{dl} .{ }^{17}$

Anemia was classified on the values of MCV and morphology of RBC as microcytic, macrocytic and normocytic anemia. In this study microcytic, macrocytic and normocytic anemia was $50.2 \%$ (101), $5 \%(10)$ and $44.8 \%(90)$ respectively. Most ( $50.2 \%)$ of the patients had microcytic anemia (Fig.-3). Among 101 patients having microcytic hypochromic anemia, IDA, beta thalassaemia trait and $\beta$ Thalassaemia were $60(59.4 \%), 10(9.9 \%)$ and $1(1 \%)$ cases respectively. The undetermined cases were $30(29.7 \%)$. The undetermined cases were those who had serum ferritin level > 12 microgram/ $L$ and $\mathrm{Hb}$ electrophoresis revealed normal and CRP was high. As ferritin is an acute phase reactant, it increases by two to four folds in Infections \& inflammation, which reduces its diagnostic value. So a majority of undetermined cases might be a case of IDA which could be detected in subsequent follow up. The prevalence of microcytic anemia was high in this study.

\section{Conclusion}

A large proportion of hospitalized children under 3 years were found anemic. Among all anemic children IDA was high. This result emphasizes the importance of identifying the risk factors of anemia in this age group. Raising awareness of the problem and providing health care education in this group will be the key strategies to prevent and control this huge public health problem in Bangladesh.

\section{References}

1. Glader B.The anemias. In: Behrman RE, Kliegman RM, Jenson HB (eds). Nelson Text book of pediatrics. $18^{\text {th }}$ ed. Philadelphia, WB Saunders co, 2003; pp. 2017.

2. Maeyer E, Adiels-Tegman M. The prevalence of anemia in the world. World Health Stat $Q$. 1985;38:302-16.

3. BBS \& UNICEF. Report on Anemia Prevalence Survey of Urban Bangladesh and Rural Chittagong Hill tracts 2003. Dhaka, BBS, 2004.

4. Hercberg S, Chauliac M, Galan P, Devanlay M, Zohoun I, Agboton Y. et al. Prevalence of iron deficiency and iron-deficiency anemia in Benin. Public Health 1988; 102:73-83. 
5. Dallman PR, Siimes MA, Stekel A. Iron deficiency in infancy and childhood. Am J Clin Nutr 1980;33: 86-18.

6. Montalembert M, Girot R. Les oligoelemements: le fer. Ricour G, Ghisolfi J, Putet G, Goulet O (eds). In: Traits de Nutrition Pediatrique. Paris, Maloine.1996;193-207. Cited in: Cornet M. Prevalence of and risk factors for anemia in young children in Southern Cameroon. Am J Trop Med Hyg. 1998;58(5): 606-11.

7. Fleming AF, Werblinska B. Anemia in childhood in the guinea savana of Nigeria. Ann Trop Paediatr. 1982; 2: 161-73.

8. Mills AF. Surveillance for anemia : risk factors in patterns of milk intake. Arch Dis Child. 1990;65:428-31.

9. UNICEF: Spotlights; "Iron, the State of the World's Children, " United Nations Children's Fund: Focus on Nutrition. 1998; p 78.

10. WHO. Hemoglobin concentrations for the diagnosis of anemia and assessment of severity. Vitamin and Mineral Nutrition Information System. Geneva, World Health Organization, 2011. Available to http://www.who.intvmins/ indicates/hemoglobin.

11. Lewis SM. Reference ranges and normal values. In : Lewis SM, Bain BJ, Bates I (eds). Dacie and Lewis Practical Hematology. $9^{\text {th }}$ ed. London Edinburgh, Churchill Livingstone, 2001;579-1587.

12. Bates I. Approach to the diagnosis of blood disease. In: Lewis SM, Bain BJ, Bates I, editors.
Dacie and Lewis Practical Hematology. $9^{\text {th }}$ ed. London Edinburgh, Churchill Livingstone, 2001; 581.

13. Schnall SF, Berliner N, Duffy TP. Approach to the Adult and child with anemia. In: Hematology, Basic principle and practice. Hoffman R, Benz EJ, Shattil SJ, Furie B, Cohen HJ, Silberstein LE(eds). $3^{\text {rd }}$ ed. London. Harcourt Health Science Co, 2000;376.

14. BBS/UNICEF. Anemia prevalence survey of Urban Bangladesh and Rural Chittagong Hill Tracts 2003. BBS /UNICEF 2005.

15. HKI \& IPHN. Anemia is a severe public health problem in pre-school children and pregnant women in rural Bangladesh. Dhaka, HKI, 2002.

16. HKI \& IPHN. Iron deficiency anemia throughout the lifecycle in rural Bangladesh. Dhaka, HKI, 1999.

17. Stallkamp G, Ached N, Keller H, The burden of anaemia in rural Bangladesh: the need for urgent action. Sight and life 2006;3:16-21.

18. Hall A, Bobrow E, Brooker S, Jukes M, Nokes $\mathrm{K}$, Lambo J, et al. Anemia in schoolchildren in eight countries in Africa and Asia. Public Health Nutr 2001;4:749-56.

19. Benoist B, McLean E, Egli I, Cogswell, M. Worldwide prevalence of anemia 1993-2005: WHO Global Database on Anemia. Geneva: World Health Organization, 2008.

20. Onyemaobi G.A, Onimawo IA. Anemia Prevalence among Under - five Children in Imo State, Nigeria. Aust. J. Basic \& Appl. Sci 2011; 5(2): 122-26. 